\title{
Proportionality and the
}

\section{Human Rights Act: a year in reflection}

\author{
by Cherie Booth QC
}

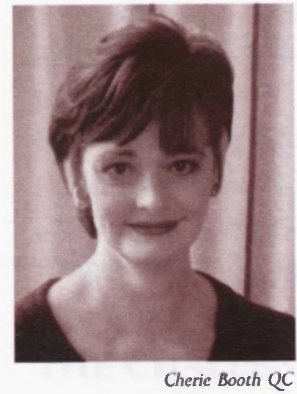

\section{INTRODUCTION}

On the second day of this month, the Human Rights Act turned one. On this, the anniversary of its commencement, it is timely to look back and reflect on its first year. For lawyers and judges alike, the Act has clearly been the "tidal wave" that Lord Woolf predicted would transform the legal landscape. It certainly has had a revolutionary effect on our way of thinking and has proved to be the single most significant change to legal practice since the invigoration of equity into the common law so many centuries ago.

Its substantive social effect has been similarly pervasive. Unquestionably, it has done far more than provide the field day for crackpots, the pain in the neck for judges and legislators, and the goldmine for lawyers that Lord McCluskey so pessimistically predicted of it. The passing of the Act has plainly led, in many cases, to the recognition and protection of fundamental rights that would have otherwise gone unrecognised and unprotected. And importantly, it appears that the Human Rights Act has begun to pervade society at large, not just our courtrooms. Its existence and the concepts that underpin it are beginning to become increasingly familiar and recognised in the community as a whole. That is what is truly needed if the Act is to achieve its ultimate aim, of creating a more equal and just society in which human rights are respected as a matter of culture and of course.

Aside from its social impact, the Human Rights Act experience in the last twelve months makes for an interesting legal analysis for us as administrative law practitioners. In particular, with the coming of the Human Rights Act we have seen the true coming of the proportionality principle, a concept that has, for some time, hovered at the edges of administrative law. That is so even though the word "proportionality" is to be found nowhere in the text of the Human Rights Act itself nor in the Convention. But quite clearly proportionality now lies at the heart of the Act and, for the first time, is the subject of daily debate in our courts when decisions of public authorities are under review.

It is the intention of this paper to:

- Explain the context in which human rights cases arise;

- briefly introduce the concept of proportionality;

- provide a synopsis of its traditional role in British law;

- briefly study its interpretation in some foreign jurisdictions; and

- analyse its application by UK Courts under the Human Rights Act in the last twelve months.

This, it is hoped, will not only be of interest to administrative law practitioners who regularly litigate or advise on cases involving the Human Rights Act, but to all administrative law practitioners given the possible impact the Act - in bringing proportionality to the fore - may have on the traditional grounds of judicial review.

\section{RIGHTS AND RESPONSIBILITIES: THE SEARCH FOR A BALANCE}

As any cursory examination of the human rights cases decided in the last twelve months will reveal, at the heart of the HRA lies a search for the fair balance between rights and freedoms. ${ }^{1}$ As we all know, rights and freedoms are rarely absolute concepts. It is truism that the freedom of one person to swing their arm extend where another person's nose begins. Rights compete against each other, and against the interests of society of a whole. The right to 
privacy conflicts with the right to freedom of expression, the right to a fair trial with the interests of society in convicting criminals. Human rights are rarely, if ever, black and white issues - rather, they involve difficult and often controversial value judgments upon which reasonable minds may differ. Lord Steyn eluded to this when he made the following comments in Brown, ${ }^{2}$ a case decided under the Human Rights Act shortly before last Christmas:

“. . . democratic government has only one raison d'être, namely to serve the interests of all the people. The inspirers of the European Convention, among whom Winston Churchill played an important role, and the framers of the European Convention, ably assisted by English draftsmen, realised that from time to time the fundamental right of one individual may conflict with the human right of another. Thus the principles of free speech and privacy may collide. They realised only too well that a single-minded concentration on the pursuit of fundamental rights of individuals to the exclusion of the interests of the wider public might be subversive of the ideal of tolerant European liberal democracies. The fundamental rights of individuals are of supreme importance but those rights are not unlimited: we live in a community of individuals who also have rights."

These competing rights and interests are balanced, and measured against each other, by applying the principle of proportionality. The European Court of Human Rights explained the underlying essence of the principle in the Soering case $^{3}$ when it said that the court must:

"search for the fair balance between the demands of the general interests of the community and the requirements of the protection of the individual's human rights".

Reduced to its simplest form, the principle requires that interference with a Convention right be proportionate to the legitimate aim being pursued by interfering with the right. As the Court of Appeal said in May in Aston Nantlow, it "calls for consideration of the appropriateness of the measure to the need which it is designed to meet". 4 Thus, judges are now required to assess the protection of rights within a framework of community interest. The legitimacy of the aim pursued by the legislation or decision in question must now be considered openly and expressly by the court in all cases that come before it. This is a rather significant change from the traditional basis for judicial review - the famous Wednesbury test ${ }^{5}$ - that allowed the court to intervene in an administrative decision only if the decision was, on its face, so perverse or irrational that no reasonable decision-maker could have reached it. The nature of this change is discussed further below.

\section{THE TRADITIONAL ROLE OF PROPORTIONALITY IN BRITISH COURTS}

British courts have traditionally not had much occasion to develop a jurisprudence of proportionality because, unlike many European jurisdictions such as Germany and France, lack of proportionality is not a ground upon which an administrative decision can be directly challenged in this country. Although in 1984 Lord Diplock suggested that it could be adopted as a free standing ground for judicial review in English law, ${ }^{6}$ and despite many other calls by judges and commentators for it to play such a role, the House of Lords made it clear a decade ago in $R v$ Secretary of State for the Home Department, ex parte Brind ${ }^{7}$ that it is not a free standing head of judicial review in British law.

At times however, especially where human rights have been involved, ${ }^{8}$ the application of Wednesbury irrationality in tradition judicial review has closely resembled the application of proportionality, and on many occasions the result of applying either test would have been identical. Thus, in Attorney-General v Guardian (No. 2), ${ }^{9}$ Lord Goff was able to say:

"It was established in the jurisprudence of the [ECHR] that . interference with freedom of expression should be no more than is proportionate to the legitimate aim pursued. I have no reason to believe that English law, as applied in the courts, leads to any different conclusion."

Lord Steyn made similar remarks in May in ex parte Daly ${ }^{10}$ but went on to note that there is a real difference between Wednesbury and proportionality:

". . there is an overlap between the traditional grounds of review and the approach of proportionality. Most cases would be decided in the same way whichever approach is adopted. But the intensity of review is somewhat greater under the proportionality approach [such that] . . the differences in approach between the traditional grounds of review and the proportionality approach may therefore sometimes yield different results". ${ }^{11}$

Clearly there is a fundamental difference between the tests: as Lord Justice Simon Brown noted in ex parte Smith ${ }^{12}$ - the famous "gays in the army case" - under the Wednesbury test the court exercises a mere secondary judgment, acting with reticence, while under the Human Rights Act the court must make a more primary judgment, closer to an analysis of the merits of the decision.

The Lord Chancellor commented prior to the commencement of the Act:

"The court's decisions will be based on a more overtly principled, and perhaps moral, basis. The court will look at the positive right. . . Moreover, the courts will in this area have to apply the Convention principle of proportionality. This means the Court will be looking substantively at that question. It will not be limited to a secondary review of the decision-making process but at the primary question of the merits of the decision itself."

Lord Steyn made a similar observation prior to the commencement of the Act:

"An assessment of the weight of moral values, such as the dictates of individualised justice as against considerations of stability and order, will be of the essence of decision making under the Act." 
Although these comments remain true, it is important to emphasise, as Lord Slynn did in Alconbury ${ }^{13}$ and Lord Justice Waller did only a fortnight ago in the recent McLellan case, ${ }^{14}$ that proportionality does not require, nor justify, merits review. The Human Rights Act is not a mandate for the courts to step into the shoes of the decision-maker and substitute their own decision if they disagree on the merits, in every case that comes before them. Quite rightly, the courts to date have followed the general Strasbourg approach and recognised that the degree to which the merits of the decision itself requires review will depend, among other things, on the nature of the right in dispute. ${ }^{15}$ In some cases, the Courts have considered it to make its own decision on the merits as part of its reviewing process, ${ }^{16}$ but in other cases the courts have applied a test closer on the spectrum to the Wednesbury reasonableness test and illustrated that, even applying proportionality, deference to the decision-maker is the proper course in many cases. ${ }^{17}$

\section{THE CHALLENGE TO BRITISH COURTS}

Despite this overlap and despite the perhaps subtle influence of proportionality in traditional judicial review, it has never been a concept applied directly in British administrative law. That is not to say that direct application of the concept is totally new for British courts, for they have on occasion been required to apply proportionality in the EC law context, where it is a fundamental principle. ${ }^{18}$

But it is really not possible to say that the English courts have had opportunity to consistently apply the doctrine of proportionality to a variety of factual scenarios. That is why the Human Rights Act, in making it a central principle, has presented such a monumental challenge to our lawyers and to our courts.

There is, however, certainly no shortage of international jurisprudence available to guide English courts as they develop an English jurisprudence of proportionality under the Human Rights Act. Obviously, the concept has been at the heart of the European Convention since its inception and the European Court of Human Rights has produced a generation of case law interpreting and applying it. And as well as playing an important role in the administrative law of many European countries, proportionality is a concept which has been interpreted and applied in Canada, New Zealand and South Africa under their various human rights instruments. To these jurisdictions, this paper will turn shortly. But first, it is logical to inspect the application of proportionality by the European Court under the Convention.

\section{PROPORTIONALITY UNDER THE EUROPEAN CONVENTION OF HUMAN RIGHTS}

Under the Convention, the European Court of Human Rights is often required to assess whether the interference with a qualified human right can be justified as being "necessary in a democratic society". Because the doctrine of proportionality is applied in making that assessment, it has become an inherent part of the Convention jurisprudencê. Quite logically, since the Human Rights Act adopts the Convention, that jurisprudence is of primary guidance to British courts. Our courts have already made clear their intention to rely upon Convention and EC law jurisprudence on proportionality. Lord Steyn, for example, said this recently in $R v . A^{19}$ :

"The criteria for determining the test of proportionality have been analysed. . . . in the case law of the Court of Justice of the European Communities and the European Court of Human Rights. It is not necessary for us to re-invent the wheel."

So, how is proportionality interpreted in Convention law? It is a fluid concept that has been applied differently at times, but it is nevertheless possible to distil the elements of the accepted test. The principle is well summarised by the three-fold test applied in Sunday Times $v$ United Kingdom, ${ }^{20}$ where the European Court of Human Rights asked the following questions:

- Is the interference complained of corresponded to a pressing social need?

- Is the interference proportionate to the legitimate aim pursued? And

- Are the reasons given to justify the interference relevant and sufficient?

The ECHR jurisprudence has also made it clear that proportionality is applied with varying degrees of strictness depending on the particular context of the case: in those cases where fundamental rights are involved, the court applies a more stringent test in those cases where property rights are involved than those in which mere property rights are concerned. ${ }^{21}$

And, although it is not explicitly recognised by Convention case law, in practice the court often applies what has been termed by commentators as the "least restrictive means" test, whereby the court will deem a measure disproportionate if the objective sought to be achieved could in fact have been achieved by a measure causing lesser impact on fundamental rights. ${ }^{22}$

\section{PROPORTIONALITY UNDER THE CANADIAN CHARTER OF RIGHTS, THE NEW ZEALAND BILL OF RIGHTS AND THE SOUTH AFRICAN CONSTITUTION}

The jurisprudence of proportionality in Canada has resulted from the need to decide disputes arising under the Canadian Charter of Rights, which guarantees the rights and freedoms set out in it but "only to such reasonable limits prescribed by law as can be demonstrably justified in a free and democratic society". 
Similarly, in New Zealand, the Bill of Rights provides that its rights and freedoms "may be subject only to such reasonable limits prescribed by law as can be demonstrably justified in a free and democratic society".

In South Africa, section 35(1) of the Constitution contains a similar proportionality test, but one which is more explicit in outlining the relevant factors to be considered by the court. It provides that the rights in the Bill of Rights:

". . . may be limited only in terms of laws of general application to the extent that the limitation is reasonable and justifiable in an open and democratic society based on human dignity, equality and freedom, having regard to all relevant factors including-

(a) the nature of the right;

(b) the importance of the purpose of the limitation;

(c) the nature and extent of the limitation;

(d) the relationship between the limitation and its purpose; and

(e) less restrictive means to achieve the purpose."

In all three of these jurisdictions, the courts have applied their expressions of the proportionality principle in a very similar manner, which in turn closely resembles the application under the Convention by the European Court of Human Rights. The principles to be distilled from the case law of these jurisdictions suggest that, for a measure to be proportionate, a number of conditions have to be satisfied:

(1) the objective sought to be achieved is necessary, is the sense that it is pressing and substantial and sufficiently important to possibly justify interference with an individual's right or freedom;

(2) the measure interfering with the fundamental right is rationally connected to that objective;

(3) the measure is necessary to achieve the objective, in the sense that it is the least drastic measure that could possibly be employed to achieve the objective; and

(4) the restriction is proportionate (in the strict sense of the word) to the measure in that it does not impose harm that is excessive to the importance of the objective.

\section{PROPORTIONALITY UNDER THE HUMAN RIGHTS ACT: THE EXPERIENCE SO FAR}

So, what has the experience here been? How have the British courts applied proportionality in the last twelve months? Have they followed Convention jurisprudence and the approach in New Zealand, Canada and South Africa?

\section{McIntosh}

The judgment of the Privy Council in the McIntosh case ${ }^{23}$ was handed down in February. The case concerned the appeal of a Scottish man who had been convicted of supplying heroin. Following his conviction, "confiscation proceedings" were commenced against him to strip him of the assets he generated by supplying drugs.

Under the Scottish legislation that authorises such proceedings, the court is permitted to draw assumptions that certain assets possessed by the convicted person are the product of his or her drug crimes, and order the confiscation of those assets accordingly.

Mr McIntosh argued that these assumptions, which the legislation permitted the court to draw, violated one of the "fair trial" rights under the European Convention, namely his right under Article 6(2), which provides:

"Everyone charged with a criminal offence shall be presumed innocent until proved guilty according to law."

$\mathrm{Mr}$ McIntosh argued that, if assumptions about the connection of his assets to his illegal activity could automatically be made adversely against him, he was, in effect, not being presumed innocent such that Article 6(2) had been violated.

Although the Privy Council decided that Article 6(2) did not in fact apply to Mr McIntosh at all - because the proceeding was not on in which he was "charged with a criminal offence" - nevertheless it went on to consider whether, if it did apply, Mr McIntosh's Convention rights would have been violated. In doing so the Court noted that what was required was a balancing act - a need to measure the general interest of the community in discouraging drug crime and stripping offenders of assets earned by that crime, against the right of an individual to a fair trial.

The Privy Council held that, in the circumstances of this case, the legislation's intrusion on the presumption of innocence was proportionate. The Privy Council noted that the degree to which the legislation impaired the presumption of innocence was relatively small - the presumptions against the defendant could only be made in circumstances where he had already been convicted of a serious crime, and the defendant could rebut these presumptions with evidence.

On the other hand - the other half of the balancing exercise - the aim pursued by the legislation was a legitimate one. The Privy Council commented that drug trafficking is a very serious social evil and noted that offenders notoriously hide their proceeds, thereby concluding that the legislation furthered the legitimate aim of protecting the community. On the balance, when the legitimate aim was measured against the degree of intrusion on the individual's right, the legislation was held to be proportionate.

It is important to note that the Court emphasised that the right given by Article 6(2) is not an absolute one, but 
rather one which could be qualified in the context of a legitimate community interest. There is a connection between the qualified nature of a right and the extent to which it may properly be violated.

\section{Brown}

The Brown case $^{24}$ concerned a Scottish woman who was suspected of stealing a bottle of gin from a 24-hour store. When the police arrived at the store, she suggested to them that she had driven there. She was charged with theft and taken to the police station where, pursuant to their powers under Scottish legislation, the police required her to state who was driving her car shortly before the alleged theft occurred. She told them it was her and she was accordingly charged with drink driving, her blood alcohol level having exceeded the legal limit.

Miss Brown argued that the legislation that required her to answer the police officer's question as to the identity of the driver of the car was contrary to Article 6(1) of the European Convention, which reads:

"In the determination of his civil rights and obligations or of any criminal charge against him, everyone is entitled to a fair and public hearing within a reasonable time by an independent and impartial tribunal established by law."

Miss Brown argued that an established aspect of this right to a fair trial was the right to remain silent and not incriminate herself.

However, like in McIntosh, the court held that the right to silence and privilege against self-incrimination were not absolute, but rather could, depending on the degree to which they were violated and the legitimacy of the goal pursued by doing so, be qualified.

The Privy Council in this case applied a similar reasoning process as was later applied in the McIntosh case.

Here, the Privy Council thought that the rights were not severely impaired because:

- Firstly, the answer to the question itself, without more, could not convict the accused. It related only to the identity of the driver and not the nature of the driving. It was only if it could also be established that Miss Brown had been drinking that she could be convicted;

- Secondly, there was in this case no suggestion that she had been coerced into providing the answer, so that its reliability was not in dispute;

- Thirdly, the power could only be exercised by or on behalf of a chief officer of police; and

- Fourthly, the admission was not necessarily final and conclusive.

Applying the balancing exercise, the Privy Council thought that the intrusion on the presumption of innocence was not a disproportionate legislative response to the problem of road safety, and that an appropriate balance had been struck between the interests of the community in preventing drink driving and the right of the individual to a fair trial. Lord Steyn, in reaching his conclusion, referred to statistics on the number of fatal and serious car accidents in recent years. The use of this type of social data is something that will no doubt become common in deciding HRA cases in which a proportionality judgment is required.

\section{Wilson}

A case in which the interference with the right was considered disproportionate to the objective pursued by such interference was Wilson, ${ }^{25}$ decided by the Court of Appeal in May 2001. The Court was required to consider the compatibility with the Convention of provisions of the Consumer Credit Act 1974, which had the effect that if a pawnbroker did not ensure that loan documentation was completed in the prescribed manner, he or she lost the ability to enforce the security for such loan. The court noted that the objective being pursued - that of ensuring customers of pawnbrokers turned their attention to the terms and conditions of the contract - was a legitimate one, the measures taken by the Parliament to achieve that objective were not proportionate to it. Even recognising that it is appropriate to defer some degree of latitude to Parliament, the Court of Appeal held that the inflexible measures taken by Parliament here were excessive. The Court was unable to deduce why Parliament though it necessary to impose such drastic consequences upon the pawnbroker for a failure to ensure paperwork was fully completed; there were other less drastic measures, such as judicial control, to protect the rights of customers. Although the Court of Appeal did not explicitly refer to it as such, the decision exemplifies the "least drastic measure" test applied in other jurisdictions. ${ }^{26}$ The balance had not been appropriately struck and, because the court was unable to give an interpretation to the provision which would make it compatible with the Convention, the Court of Appeal issued a declaration of incompatibility in relation to it, one of only three such declarations issued to date.

Proportionality was also found to not exist in the case of Aston Cantlow and Wilmcote with Billesley Parochial Church Council v Wallbank and another, ${ }^{27}$ a case decided in May. In this case the freehold owners of certain glebe land challenged their liability under an old common law to pay the costs of keeping the parish church in repair. The court noted that this liability was imposed arbitrarily and discriminatorily, for the obligation to pay had no necessary connection with the parish itself. The Court queried whether the common law rule in question violated the Convention, and said:

"The turns on proportionality. Proportionality, in the jurisprudence both of the European Court of Human Rights and of the Court of Justice of the European Communities, calls for a 
consideration of the appropriateness of the measure to the need which it is designed to meet. The need here is the legitimate one of maintaining historic buildings in the public interest. The means employed, however, are a tax . . levied exclusively on the owners of the land which has for centuries been divorced from the system of rights and responsibilities with which ecclesiastical law clothed the rectories of which the land once formed part." 28

The court - again without specifically referring to the principle as such - seems to apply some form of the "least drastic means" test, by referring to fact that the state possesses a large choice of measure to control the use or property or to redistribute wealth. It would have been possible for the state to achieve its legitimate objective of upkeeping historic buildings by imposing one of many other forms of taxation in which a closer relationship was achieved between the form of taxation and that objective.

In $R \vee A$, Lord Hope of Craighead seemed to expressly endorse the "least drastic measure" test:

"The question is whether these provisions have achieved a fair balance. This will be achieved if they do not go beyond what is necessary to accomplish their objective. That is the essence, in this context, of the principle of proportionality." 29

And in one of the most recent HRA cases, Samaroo, ${ }^{30}$ Lord Justice Dyson made it clear that it is important question for the court to address, saying that the question at the first stage is "can the objective of the measure be achieved by means which are less interfering of an individual's rights?'.

\section{JUDICIAL RESTRAINT}

Decisions such as Brown and McIntosh show that political, social and moral philosophy cannot be divorced from human rights. And because of this, the view of the democratic legislature should always be taken very seriously on these issues. At times the courts have rightly recognised this in applying proportionality - that it is appropriate to defer to Parliament when considering whether rights and responsibilities have been properly weighed against each other. For example, in $R v A$, Lord Hopehead said:

"It is plain that the question is in the end one of balance. Has the balance between the protection of the complainant and the accused's right to a fair trial been struck in the right place? .

if any doubt remains on the matter, it raises the further question whether Parliament acted within its discretionary area of judgment when it was choosing the point of balance indicated by s41. The area is one whether Parliament was better equipped than the judges are to decide where the balance lay. The judges are well able to assess the extent to which the restriction will inhibit questioning or the leading of evidence. But it seems to me that in this highly sensitive and carefully researched field an assessment of the prejudice to the wider interests of the community if the restrictions were not to take that form was more appropriate for Parliament. An important factor for Parliament to consider was the extent to which restrictions were needed in order to restore and maintain public confidence". 31

And:

"I would take, as my starting point ... the proposition that there are areas of law which lie within the discretionary area of judgment which the court ought to accord to the legislature. As I said in . . Kebeline . . .it is appropriate in some circumstances for the judiciary to defer, on democratic grounds, to the considered opinion of the elected body as to where the balance is to be struck between the rights of the individual and the needs of society." 32

Lord Woolf CJ expressed a similar opinion in $R v$ Lambert and others ${ }^{33}$ :

"It is . . important to have in mind that legislation is passed by a democratically elected Parliament and therefore the courts under the convention are entitled to and should, as a matter of constitutional principle, pay a degree of deference to the view of Parliament as to what is in the interest of the public generally when upholding the rights of the individual under the convention."

The courts have rightly recognised that in some fields more than others, Parliament should be granted a degree of latitude. Where the issue at stake is one in which Parliament has specifically considered and legislated specifically to reflect the will of the electorate, the courts are less likely to declare the measure disproportionate. ${ }^{34}$ Where, however, the courts are themselves most qualified to judge the necessity of a provision, such as those which regulate court procedure, or where the interference relates to a fundamental right of high constitutional importance such as the right to freedom from torture, the courts will afford Parliament a lesser degree of latitude. ${ }^{35}$ For example, in $R_{v} A$, Lord Steyn made the comment:

"Clearly the House must give weight to the decision of Parliament. ... On the other hand, when the question arises whether in the criminal statute in question Parliament adopted a legislative scheme which makes an excessive inroad into the right to a fair trial the court is qualified to make its own judgment and must do so". 36

As recently as 11 October 2001 the same sentiments are to found in the judgment of Lord Hoffman in Secretary of State for the Home Department $v$ Rehman ${ }^{37}$ concerning the power of the Secretary of State to deport suspected terrorists. Mr Rehman was a Pakistani national with temporary leave to stay in the United Kingdom. A security service assessment concluded that he was involved with an Islamic terrorist organisation, and that while it was unlikely that he would commit acts of violence in the United Kingdom, his activities here were intended to further the cause of a terrorist organisation abroad. On that basis, the Secretary of State concluded that $\mathrm{Mr}$ Rehman posed a threat to national security and that he should therefore be deported. The Special Immigration Appeals Commission held on appeal that a person 
offended against national security only if he engaged in, promoted or encouraged violent activities targeted at the United Kingdom, its system of government or its people. That decision was overturned by the Court of Appeal and by the House of Lords.

Lord Hoffman in his speech ${ }^{38}$ said this:

"In my opinion the fundamental flaw in the reasoning of the Commission was that although they correctly said that section 4(1) gave them full jurisdiction to decide questions of fact and law, they did not make sufficient allowance for certain inherent limitations, first, in the powers of the judicial branch of government and secondly, within the judicial function, in the appellate process. First, the limitations on the judicial power. These arise from the principle of the separation of powers. The Commission is a court, a member of the judicial branch of government. It was created as such to comply with article 6 of the Convention for the Protection of Human Rights and Fundamental Freedoms (1953) (Cmnd 8969). However broad the jurisdiction of a court or tribunal, whether at first instance or on appeal, it is exercising a judicial function and the exercise of that function must recognise the constitutional boundaries between judicial, executive and legislative power. Secondly, the limitations on the appellate process. They arise from the need, in matters of judgment and evaluation of evidence, to show proper deference to the primary decision-maker."

These comments show that the approach of British courts under the Human Rights Act will be similar to that adopted by the Canadian Supreme Court under the Canadian Charter, expressed in the following words:

"This Court has pointed out on a number of occasions that in the social, economic and political spheres, where the legislature must reconcile competing interests in choosing one policy among several that might be acceptable, the courts must accord great deference to the legislature's choice because it is in the best position to make such a choice. On the other hand, the courts will judge the legislature's choice more harshly in areas where the government plays the role of the 'singular antagonist of the individual - primarily in criminal matters owing to their expertise in this area ... ."' 39

Justice La Forest similarly explained in RJR-McDonald Inc ${ }_{v}$ Canada $(A-G)^{40}$.

"Courts are specialists in the protection of liberty and the interpretation of legislation and are, accordingly, well places to subject criminal justice legislation to careful scrutiny. However, courts are not specialists in the realm of policy making, nor should they be. This is a role properly assigned to the elected representatives of the people, who have at their disposal the necessary institutional resources to enable them to compile and assess social science evidence, to mediate between competing social interests and protect vulnerable groups."

Interestingly, though, the House of Lords in $R v A$ was not in agreement as to whether the issue in question was one in which Parliament, or the Courts, were most qualified to decide on the appropriate balance between rights and community interests. In that case, the issue was whether it was legitimate for legislation to preclude an accused charged with rape from cross-examining the complainant about her sexual history. Lord Hopehead concluded that the areas was one where Parliament was better equipped than the judges to decide where the balance lay; in his opinion it was a highly sensitive and carefully researched field which involves an assessment of prejudice to wider interests of the community, and that it was an important factor for Parliament to consider the extent to which restrictions were needed in order to restore and maintain public confidence. ${ }^{41}$ Lord Steyn however noted that in a criminal statute when the question arises as to whether Parliament has made excessive inroads into the right to a fair trial, the court is qualified to make its own judgment and must do so. ${ }^{42}$

And while the courts have shown a willingness to defer to Parliament, they have also made it clear that they will not do so blindly and that they are prepared to analyse the reasons Parliament considered a particular measure necessary. The courts have emphasised that deference is not the same as unquestioning acceptance. In Wilson for example, the court noted:

"It is one thing to accept the need to defer to an opinion which can bee seen to be the product of reasoned consideration based on policy; it is quite another thing to be required to accept, without question an opinion for which no reason of policy is advanced." 43

The court in that case attempted to understand why Parliament had enacted what it considered to be an excessive measure to achieve its objective, but being unable to answer that question after looking at material such as Parliamentary debates, it concluded that the measure was disproportionate. In contrast, in $R_{V}$ Lambert and others, Lord Woolf expressly stated that he could "well understand" why, in light of the legitimate social aim being pursued, Parliament interfered with the right in question in that case and the manner in which it did so.

The line between proper deference to Parliament, and improper intrusion on the sovereignty of Parliament and discretion of a decision maker, is a fine one. On the right balance, opinions will differ. But the coming of the Human Rights Act should not be seen as a licence for the judiciary to usurp executive and legislative power. In Brind, ${ }^{44}$ Lord Lowry warned of the dangers of proportionality:

"(1) The decision-makers, very often elected, are those to whom Parliament has entrusted the discretion and to interfere with that discretion beyond the limits as hitherto defined would itself be an abuse of the judges' supervisory jurisdiction. (2) The judges are not, generally speaking, equipped by training or experience, or furnished with the requisite knowledge and advice, to decide the answer to an administrative problem where the scales are evenly balanced, but they have a much better chance of 
reaching the right answer where the question is put in a Wednesbury form ... (3) Stability and relative certainty would be jeopardised if the new doctrine held sway, because there is nearly always something to be said against an administrative decision and parties who felt aggrieved would be even more likely than at present to try their luck with judicial review application

(4) The increase in applications for judicial review of administrative action (inevitable if the threshold of unreasonableness is lowered) will lead to the expenditure of time and money by litigants, not to speak of the prolongation of uncertainty for all concerned with the decisions in questions, and the taking up of court time which could otherwise be devoted to other matters. The losers in this respect will be members of the public, for whom the courts provide a service".

Although these comments were made in the context of rejecting proportionality as a new ground of judicial review, the dangers of which Lord Lowry warned remain relevant under the Human Rights Act. Proportionality can be taken too far and the courts must be wary not to go too far, even under the greater scope afforded to them under the Human Rights Act. A degree of judicial reticence is required. The courts should not see the Act as a licence to superimpose their own opinions for those of Parliament or decision-makers, for a margin of discretion should remain with them. The extent of that latitude will depend on many factors, such as the nature of the fundamental right in question, but as Lord Steyn pointed out in Daly, ${ }^{45}$ under the Human Rights Act there has not been a shift to merits review. The roles of judges, legislators and administrators are distinct and must remain so. This is inherent in the entire scheme of the Human Rights Act.

\section{AN IMPACT ON THE TRADITIONAL BASIS OF JUDICIAL REVIEW?}

So it is clear that proportionality lies at the heart of the Human Rights Act, and that our courts are applying the concept consistently with the manner in which it is applied under Convention law, and in foreign jurisdictions. And it is possible that, as our courts become more comfortable with the concept, proportionality may begin to pervade areas of law other than human rights. In particular, despite the views of those such as Lord Lowry who have voiced fears of the danger of doing so, it may be that the Human Rights Act is the catalyst that causes proportionality to be accepted as an independent head of judicial review in administrative law.

In this respect, Lord Cooke's comments in ex parte Daly are interesting:

". . . I think that the day will come when it will be more widely recognised that Associated Provincial Picture Houses Ltd v Wednesbury Corporation [1948] 1 KB 223 was an unfortunately retrogressive decision in English administrative law, insofar as it is suggested that there are degrees of unreasonableness and that only a very extreme degree can bring an administrative decision within the legitimate scope of judicial invalidation. The depth of judicial review and the deference due to administrative discretion vary with the subject matter. It may well be, however, that the law can never be satisfied in any administrative field merely by a finding that the decision under review is not capricious or absurd."

Lord Slynn has similarly advocated a wider role for proportionality, saying in Alconbury ${ }^{46}$ :

"... even without reference to the Human Rights Act the time has come to recognise that this principle (of proportionality) is part of English administrative law, not only when judges are dealing with Community Acts but also when they are dealing with acts subject to domestic law."

Time will tell, but watch this space.

Cherie Booth QC, Barrister-at-Law and founding member of Matrix chambers.

This paper was presented to the Institute of Advanced Legal Studies seminar on 29 October 2001

1 This was expressly recognised by Lord Justice Dyson in $R$ (on the application of Samaroo) v Secretary of State for the Home Department [2001] All ER (D) 215, 17 July 2001 at para 26. See also the similar expression of proportionality by La Forest J of the Canadian Supreme Court in Ross $v$ New Brunswick School District No 15 [1996] 1 SCR 825 at 872.

2 Brown v Stott (Procurator Fiscal, Dunfermline) and another [2001] 2 All ER 97.

3 Soering v United Kingdom (1989) 11 EHRR 439, para 89.

4 Aston Nantlow and others $v$ Wallbank and another [2001] 3 All ER 393 at [51].

5 [1948] $1 \mathrm{~KB} 223$.

6 Council of the Civil Service Unions v Minister for the Civil Service [1985] AC 374 at 410,

7 [1991] 1 AC 696.

8 Such as in $R v$ Ministry of Defence, ex $p$ Smith [1996] QB 517.

$9 \quad[1990] 1 \mathrm{AC} 109$ at 283.

$10 R v$ Secretary of State for the Home Department, ex parte Daly [2001] UKHL 26, 23 May 2001 at paragraph 27.

11 See also $R$ (on the application of Samaroo) v Secretary of State for the Home Department [2001] All ER (D) 215, 17 July 2001 at para 39.

12 [1996] QB 517 at 541.

13 At [51]-[52].

14 McLellan; Bracknell Forest Borough Council and Secretary of State for Transport, Local Government and the Regions $v$ Reigate \& Banstead Borough Council and others [2001] EWCA Civ 1510 (16 October 2001) at [95].

15 See $W_{V} U K(1988) 10$ EHRR 29.

16 See for example, X v Secretary of State for the Home Department [2000] All ER (D) 2162.

17 See for example, $R$ (Mahmood) v Secretary of State for the Home Department [2001] 1 WLR 840.

18 See for example $R v$ Human Fertilisation and Embryology Authority, ex parte Blood [1997] 2 WLR 8-7; $U_{V} W$ [1997] 3 WLR 739.

19 [2001] 3 All ER 1 at [38]. 
21 For example, contrast the strict test in the right to life case of McCann v United Kingdom (1996) 21 EHRR 97 with the right to property case of Lithgow $v$ United Kingdom (1986) 8 EHRR 329. 137; Open Door Counselling and Dublin Well Woman v Ireland (1992) 15 EHRR 244; Ahmed v United Kingdom [1999] IRLR 188. McIntosh v Lord Advocate and another [2001] 2 All ER 638.

Brown v Stott (Procurator Fiscal, Dunfermline) and another [2001] 2 All ER 97.

25 Wilson v First County Trust Ltd [2001] 3 All ER 229

26 Another case exemplifying the least drastic measures test in practice is $R v$. Secretary of State for the Home Department, ex parte Daly [2001] UKHL 26 (23 May 2001). There it was noted that the policy for searching prisoner's cells, by imposing a blanket rule of routinely excluding prisoners, could not be justified as the objective of that policy could have been achieved by other search methods.

27 [2001] 3 All ER 393.

28 At [51].

29 At [94].

$30 \quad R$ (on the application of Samaroo) v Secretary of State for the Home Department [2001] All ER (D) 215, 17 July 2001 at para 19.

31 At [99]. for the Home Department [2001] All ER (D) 215, 17 July 2001 at para 36 where Lord Justice Dyson noted that the Secretary of State should be afforded a significant margin of appreciation in the decision whether to deport a foreign national convicted of serious offences in the UK because the court does not have expertise is judging how effective a deterrent such a policy is.

See $R v$ DPP; ex p Kebeline [1999] 4 All ER 801 at 844.

At [36].

[2001] UKHL 47

At [49].

Libman v A-G of Quebec (1997) 151 DLR (4th) 385.

(1995) 127 DLR (4th) 1

At [99].

At [36].

At [33].

ex parte Brind (1991) 1 AC 696 at 766-777

$R$ (Daly) $v$ Secretary of State for the Home Department [2001] 2 WLR 1622 at $1636 \mathrm{~B}$.

46 [2001] UKHL 23 at para 50

\section{Privacy and celebrity 2} by Michael Tugendhat QC

The author concludes his two-part study of privacy and celebrity by posing the vention of whether claims hsould be brought in libel or confidentiality.

A $s$ things stand, the lawyers choose the cause of action depending on what the client says about the truth of the information. If the client says the allegation is false, the claim is brought in libel. If the client says it is true, it is brought in confidentiality. But should the claimant have to say whether he has an eating disorder or not? And what if the publication complained of is a gross exaggeration? Suppose the client has only a small or temporary eating disorder, which cause of action does he choose? Does he have to confirm or deny?

\section{THE PRINCIPLES OF LAW ON PERSONAL INFORMATION}

These questions cannot be answered by citation of precedent. Judges will be guided by principle. So there are other prior questions of a higher order. Why has English law hitherto regarded truth as justifying publication of almost all personal information? What are the values of freedom of expression and reputation protected by libel? What are the values protected by privacy laws?

\section{The value of reputation}

It is easy to start with libel. The answer has been given by Lord Nicholls in Reynolds $v$ Times [1999] 3 WLR 1010, 1023. He said:

'Reputation is an integral and important part of the dignity of the individual. It also forms the basis of many decisions in a democratic society, which are fundamental to its well-being: whom to employ or work for, whom to promote, whom to do business with or to vote for. Once besmirched by an unfounded allegation in a national newspaper, a reputation can be damaged forever, especially if there is no opportunity to vindicate one's reputation. When this happens, society as well as the individual is the loser. For it should not be supposed that protection of reputation is a matter of importance only to the affected individual and his family. Protection of reputation is conducive to the public good. It is in the public interest that the reputation of public figures should not be debased falsely. In the political field, in order to make an informed, choice, the electorate needs to be able to identify the good as well as the bad. Consistently with these considerations, human rights conventions recognise that 